Patimo, D.M. \& Lucero, M.B.A., Predictors of Success in Advance Higher Education: A Case in Northwest Samar State University, Philippines

\title{
Predictors of Success in Advance Higher Education: A Case in Northwest Samar State University, Philippines
}

\author{
Donald M. Patimo* \\ Northwest Samar State University, Calbayog, Philippines \\ Ma. Bernadette A. Lucero \\ Northwest Samar State University, Calbayog, Philippines \\ *Corresponding Author: donald.patimo@nwssu.edu.ph \\ Received : 2020-11-08 \\ Revised : 2021-03-12 \\ Accepted : 2021-04-29
}

$10.46303 /$ ressat.2021.3

How to cite this paper: Patimo, D.M. \& Lucero, M. B. A. (2021). Predictors of Success in Advance Higher Education: A Case in Northwest Samar State University, Philippines. Research in Social Sciences and Technology, 6 (1), 40-52. https://doi.org/10.46303/ressat.2021.3

This is an Open Access article distributed under the terms of the Creative Commons Attribution 4.0 International license (https://creativecommons.org/licenses/by/4.0/).

\begin{abstract}
Teachers play a significant role in the preparation of our youth as they make important decisions about education, work, and life. Existing studies on the correlations between teaching proficiency and academic performance of the students are primarily limited to elementary, secondary, and tertiary levels. Considering the big difference between advance higher education and other educational levels, there is a need to explore the relationship of the teaching proficiency to the academic performance of the students in advance higher education. This study made use of the descriptive-correlation research design. Survey questionnaires were distributed to all advance higher education faculty members and students from School Years 2015 to 2017 at Northwest Samar State University. Statistical tools like frequency and percentage distribution, means, standard deviations, and regression analysis were used for the analysis of the data. Results showed that most of the advance higher education faculty members are male, married, doctorate holders, professionals, researchoriented, very satisfactory performers, and possess good financial status. The best predictor of the academic performance of the advance higher education students is the work experience of the faculty members.
\end{abstract}

Keywords: Teaching Proficiency, Academic Performance, Graduate Education 
Patimo, D.M. \& Lucero, M.B.A., Predictors of Success in Advance Higher Education: A Case in Northwest Samar State University, Philippines

\section{Introduction}

Teachers play a significant role in the preparation of our youth as they make important decisions about education, work, and life. Clarke et al (2010) observed that the teachers' appreciation of the subject matter involved can directly influence the learning opportunities of the students. Denessen et al (2015) added that female teachers showed less positive attitudes towards teaching than male teachers which contributes to the less positive attitude of their students.

Hamilton et al (2015) postulated that a teacher has more influence compare to any other school factors, including leadership, services, and facilities. Their research also suggested that the individual and family characteristics may have great impact on student achievement when compared with teachers. Another interesting finding on their study was the best way to assess teacher's effectiveness by looking at their work performance.

In another study, the teacher's conferences and workshops attended, qualification, and published papers are not related to teaching performance (Hashmi et al, 2011). On the other hand, Bulut and Yilmaz (2014) found a meaningful correlation between math teachers' democratic conduct in the students' learning process and success in mathematics. In addition, Morteza and Khademi (2015) suggested that teachers' sources of pedagogical beliefs and teaching experiences were predictors of the learners' outcomes.

Existing studies such as mentioned above on the correlations between teaching proficiency and academic performance of the students are primarily limited to elementary, secondary, and tertiary levels. Considering the big difference between advance higher education and other educational levels, there is a need to explore the relationship of the teaching proficiency to the academic performance of the students in advance higher education.

Furthermore, graduate work has varied activities from theories to the conduct of researches and as such Gwen (2011) enumerated points of difference between graduate education and other levels of education. According to him, graduate programs are advanced and highly specialized than the other levels of education in the country. Elementary, secondary, and tertiary classes are usually larger and less individualized compared to the individual students or small groups work closely supervised with professors in graduate studies. Graduate programs are much more research-oriented while undergraduate programs are focused on instructions (Dinh, 2019; Lee \& Lee, 2020;).

Noteworthy is to explore the current trends that are far more advanced with practical applications that the content of such knowledge imparted may improve the craft and skills of the advance higher education students. Likewise, this study may imbibe in determining the weaknesses of the students on the lack of the needed knowledge shall be capitalized as the starting point for this undertaking. 
Patimo, D.M. \& Lucero, M.B.A., Predictors of Success in Advance Higher Education: A Case in Northwest Samar State University, Philippines

In Northwest Samar State University (NwSSU), many advance higher education students failed in their comprehensive examination. For the last five semesters and summers, the failure rate of the advance higher education students ranges from 18 to 59 percent. Hence, this study was conducted. Specifically, this study sought answers to the following research questions. First, the study aimed to identify the profile of the advance higher education faculty members in terms of age, civil status, sex, highest educational attainment, work experience, relevant training/seminars attended, net take home pay, number of researches conducted, and performance rating of the advance higher education faculty members. Also, the study tried to identify the academic performance of the advance higher education students in terms of their basic, major, and elective subjects. Finally, the study shall determine the profile variable of the advance higher education faculty members that best predict the academic performance of their students.

\section{Data and Method}

A lot of people have looked up at teachers with a beaming awe, a high regard, strongly believing in them, where they placed their confidence in them for they were assumed that they will find ways and means to reach out to students amidst difficulties and go through the rigors to effectively reach out to students. Waychunas (2020) mentioned of exploring schools that were "beating the odds" to identify odd practices. This notion of giving out the best to be effective encompasses the proper mind set, the preparation of oneself, and a noble heart for the best of the students (Wenner \& Campbell, 2017). And in this light, the aim to harness on skill and be one with technology has geared toward the notion of Education 4.0, a lifelong affair with industry (Pangandaman, Ali, Lambayong, \& Ergas, 2019).

The graduate school as being composed mainly of students coming from different organizations and institutions of varied interest may be effective in relating theories to practice. Thus, Wren and Wren (2009) give emphasis on the useful experience of the students in the graduate level of education. Furthermore, the training and practice would seem to be favorable hands-on learnings of the students.

The predictors of success rather have its measuring factors such as to look into the students' academic success in higher education the student demographics, like gender, the socio economic factors as adhered by Alyahyan and Dustegor (2020) were of paramount importance. In the same manner, we may look into the trends of education that the needed skill be imbibed as part of what teachers may adapt the technology. Another issue is the present conditions of the COVID-19 pandemic where we encountered a lot of problems in the delivery of the instructions to the students. The research of Pokhrel and Chhetri (2021) accordingly highlights certain dearth such as weakness of online teaching infrastructure and the limited exposure of teacher to online teaching. McCorkle (2020) mentioned that schooling has changed for most people and that it is a big challenge in the academe as to how to show leadership in the middle of these circumstances. 
Patimo, D.M. \& Lucero, M.B.A., Predictors of Success in Advance Higher Education: A Case in Northwest Samar State University, Philippines

This study was primarily based on the idea that teachers matter most to the students' academic performance (Hamilton et al, 2015). Torabi and Zahiri (2012) found out that characters such as ethics and humility of teachers have the most influence according to the students' views. The effects of professional, scientific, and physical environment factors were assessed as ineffective in student-teacher relationship. Another study found that other teacher characteristics coupled with classroom practices are comparable in size to those of student background (Wenglinsky, 2001). Bhatti and Qazi (2011) found out that the students' scores on their Grade Point Averages (GPAs) have better academic competence.

Teachers are considered moulders of the minds, they as well influence the students in more ways and instill memories of seen good and great examples of what their teachers have shown in their real lives. Bilbao et al (2012) further emphasized that teachers are considered as professionals with competent skills observes high standards of the job, and abides by the code of ethics. Teachers demonstrate leadership who made great influence not only for their students but also extends beyond their own classrooms to others within their own school and the whole community (Danielson, 2006).

The conceptual framework of the study is shown in the figure below. The inputs of this study involve the profile of the advance higher education faculty members and students. These inputs were collected and processed with the academic performance of the advance higher education students through the descriptive-correlation method of research with the use of questionnaires and interview guides. The result of the assessment determined the predictors of success in advance higher education.

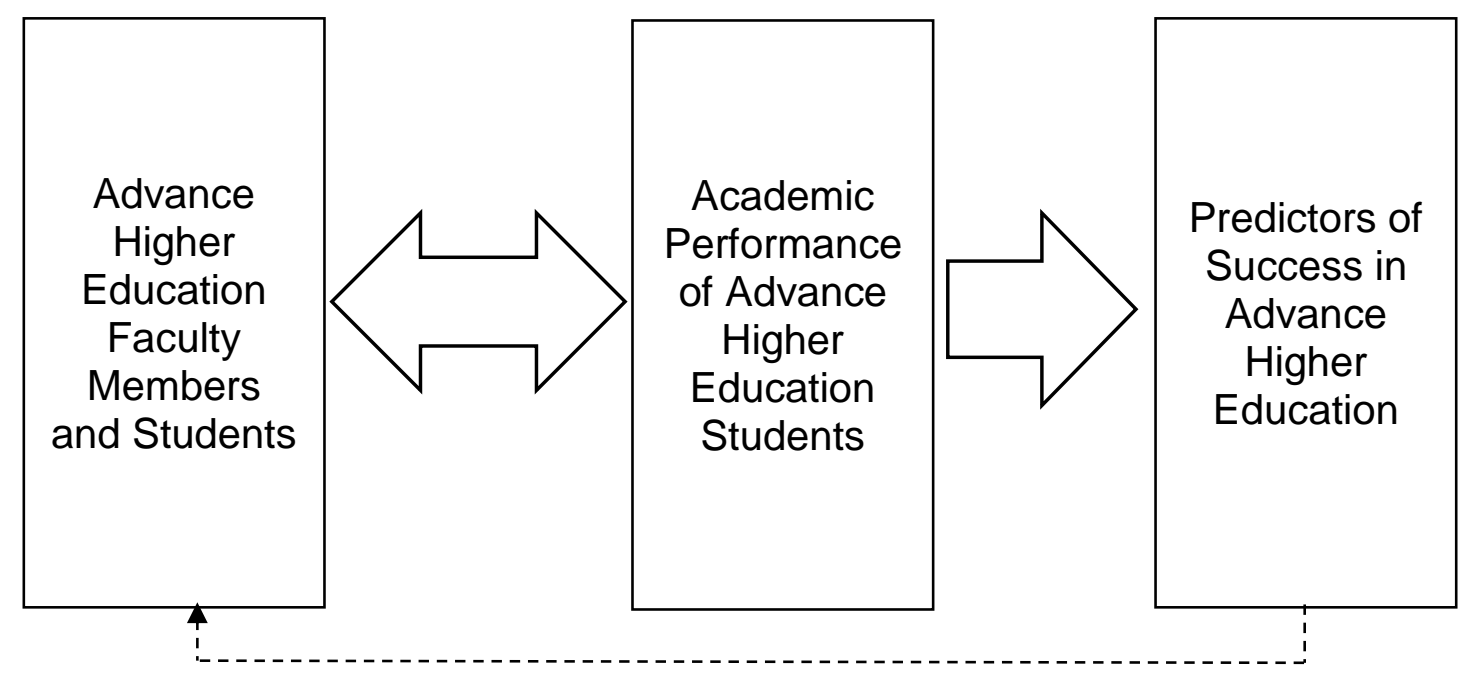

Figure 1. Conceptual Framework of the Study 
Patimo, D.M. \& Lucero, M.B.A., Predictors of Success in Advance Higher Education: A Case in Northwest Samar State University, Philippines

\section{Data and Method}

Design

Descriptive-correlation research design was used in this study. The study aimed to identify the profile of the advance higher education faculty members and the academic performance of their students in basic, major, and elective subjects. Among the profile variables of the advance higher education faculty members, the study shall determine the best predictor of academic performance of their students.

Sample

A total enumeration of advance higher education faculty members and students from School Years 2015 to 2017 were considered in the study. The study was conducted at the Main Campus of the Northwest Samar State University in Calbayog City. With this, all advanced higher education faculty members in total of 19 and all advance higher education students in total of 197 were considered in the study.

\section{Instruments}

The survey questionnaire utilized in this research study was constructed by the researchers to elicit the needed data for the personal profile of the advanced higher education faculty members. The questionnaire specifically asked for the age, civil status, sex, highest educational attainment, work experience, relevant training/seminars attended, net take home pay, number of researches conducted, and performance rating of the advance higher education faculty members. For the grades of the basic, major, and elective subjects of the advance higher education students, the researchers asked for this data with the university registrar.

Data Collection

Data collection for this study started with a letter of request addressed to the university president of the state university seeking permission to conduct the study. Upon approval, the researchers personally distributed the questionnaires to the respondents of the study. Full explanation of the purpose and importance of the study and how the instrument should be accomplished were explained to the respondents in order to solicit their cooperation. Data from the accomplished questionnaires were analyzed, presented, and summarized. The same permission from the university president was presented to the university registrar in order to get the actual grades of the advance higher education students on basic, major, and elective subjects. 
Patimo, D.M. \& Lucero, M.B.A., Predictors of Success in Advance Higher Education: A Case in Northwest Samar State University, Philippines

Data Analysis

Data analysis for this study began with a data cleaning process where non-response and erroneous data were removed from the data set to improve accuracy of the overall analysis. The researchers then employed descriptive statistical analyses using statistical software to summarize the data collected in this study. Statistical tools like frequency and percentage distribution, means, standard deviations, and regression analysis were used for the analysis of the data.

\section{Results and Discussions}

This section presents, analyzes, and interprets the data to answer the problems raised in this study. The discussion includes the profile of the advance higher education faculty members and students, academic performance of the advance higher education students, relationship between the profile of the respondents and the academic performance, and the profile factors that can best determine the students' academic performance.

The first research question of this study was to identify the profile of the advance higher education faculty members in terms of age, civil status, sex, highest educational attainment, work experience, relevant training/seminars attended, net take home pay, number of researches conducted, and performance rating of the advance higher education faculty members. Table 1 presents the frequency and percentage distribution on the profile of the advance higher education faculty members. In terms of age, analysis of the data on the mean and standard deviation revealed that the majority of the advance higher education faculty members are mature adults who reached the apex of their teaching career. 
Patimo, D.M. \& Lucero, M.B.A., Predictors of Success in Advance Higher Education: A Case in Northwest Samar State University, Philippines

Table 1: Frequency and Percentage Distribution on the Profile of the Advance Higher Education Faculty Members in terms of Age, Civil Status, Sex, Highest Educational Attainment, Work Experience, and Relevant Training/Seminars Attended

\begin{tabular}{|c|c|c|}
\hline Variables & Frequency & Percentage \\
\hline $\begin{array}{l}\text { AGE (in years) } \\
\qquad \begin{array}{c}40 \text { and below } \\
41-50 \\
\end{array} \\
\text { TOTALS }\end{array}$ & $\begin{array}{c}7 \\
5 \\
9 \\
21\end{array}$ & $\begin{array}{c}33.30 \\
23.80 \\
42.90 \\
100.00\end{array}$ \\
\hline $\begin{array}{l}\text { Mean Age } \\
\text { Standard Deviation }\end{array}$ & \multicolumn{2}{|c|}{47.95 years } \\
\hline $\begin{array}{lc}\text { SEX } & \text { Male } \\
& \text { Female } \\
\text { TOTALS } & \\
\end{array}$ & $\begin{array}{c}12 \\
9 \\
21 \\
\end{array}$ & $\begin{array}{c}57.10 \\
42.90 \\
100.00 \\
\end{array}$ \\
\hline $\begin{array}{lc}\text { CIVIL STATUS } & \begin{array}{c}\text { Single } \\
\text { Married } \\
\text { Widow/er }\end{array} \\
\text { TOTALS } & \end{array}$ & $\begin{array}{c}6 \\
12 \\
3 \\
21\end{array}$ & $\begin{array}{c}28.60 \\
57.10 \\
14.30 \\
100.00\end{array}$ \\
\hline $\begin{array}{l}\text { HIGHEST EDUCATIONAL ATTAINMENT } \\
\text { Master's Degree Holder } \\
\text { Doctorate Degree Holder } \\
\text { TOTALS }\end{array}$ & $\begin{array}{c}6 \\
15 \\
21\end{array}$ & $\begin{array}{c}28.60 \\
71.40 \\
100.00\end{array}$ \\
\hline $\begin{array}{l}\text { WORK EXPERIENCE (in years) } \\
\qquad \begin{array}{c}10 \text { and below } \\
11-20 \\
21-30\end{array} \\
\text { TOTALS }\end{array}$ & $\begin{array}{c}2 \\
10 \\
7 \\
2 \\
21\end{array}$ & $\begin{array}{c}9.50 \\
47.60 \\
33.30 \\
9.50 \\
100.00\end{array}$ \\
\hline $\begin{array}{l}\text { Mean Work Experience } \\
\text { Standard Deviation }\end{array}$ & & \\
\hline
\end{tabular}

The majority of the advance higher education faculty members were male, married, and doctorate holders. The mean work experience and standard deviation showed that most of the advance higher education faculty members practiced already their profession in a long period and may acquire valuable exposure in the field of teaching with professional students. The same profile variables on age, sex, educational background and years of teaching were considered in the study of Monga and Ye (2020) on teachers' perceptions towards interpersonal relationship and working environment at Roong Aroon School, one of the graduate schools in Thailand.

Table 2 presents the frequency and percentage distribution on the profile of advance higher education faculty members concerning the number of relevant trainings/seminars 
Patimo, D.M. \& Lucero, M.B.A., Predictors of Success in Advance Higher Education: A Case in Northwest Samar State University, Philippines

attended, net take-home pay, number of researches conducted, and performance rating. The mean number of relevant trainings/seminars attended by the advance higher education faculty members of the university displayed the support of the administration concerning their education and other teaching competencies. In terms of net take-home pay, the analysis of the computed mean and standard deviation can show the good financial status of the advance higher education faculty members of the university.

Table 2: Frequency and Percentage Distribution on the Profile of the Advance Higher Education Faculty Members in terms of Net Take Home Pay, Number of Researches Conducted, and Performance Rating

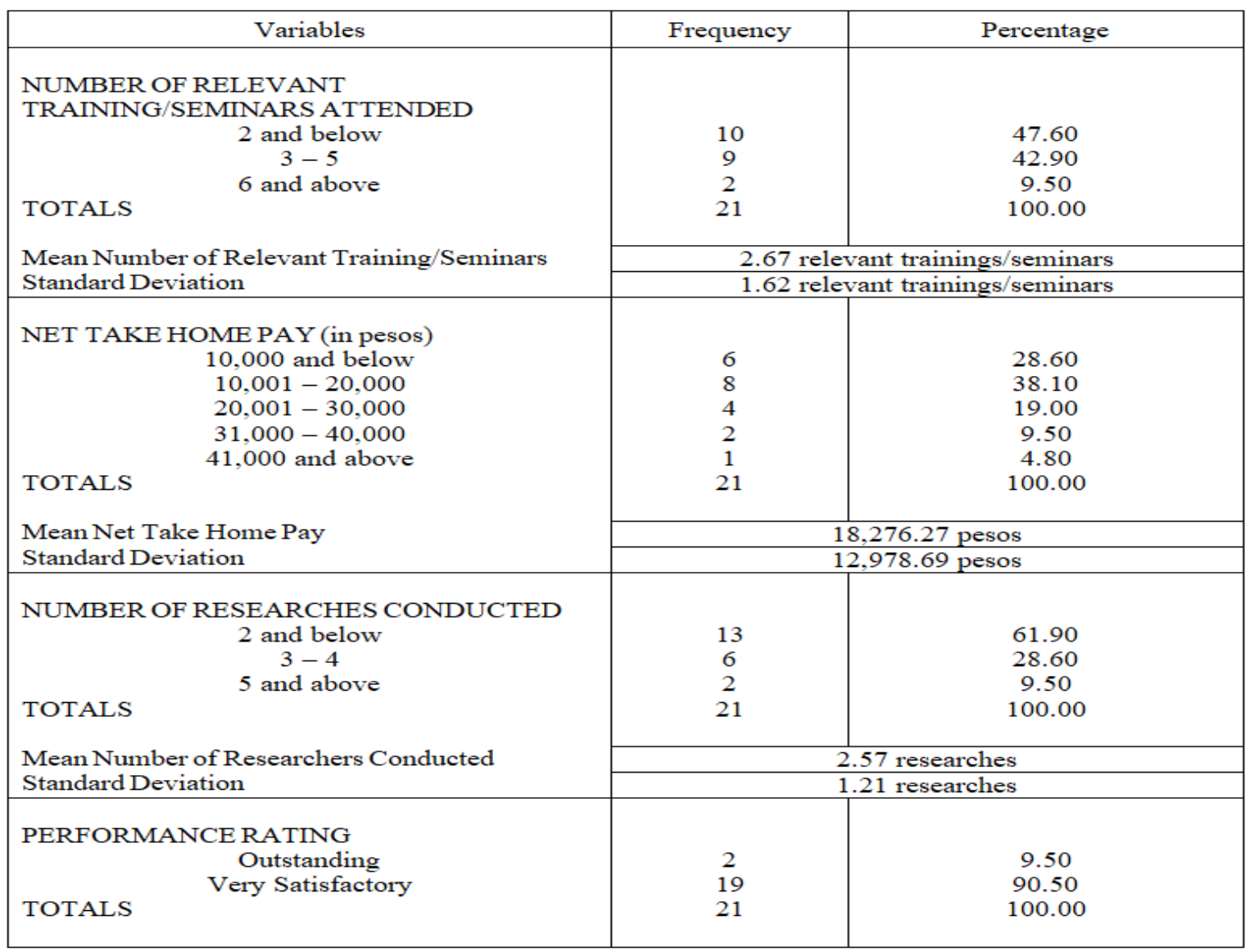

Also, the mean and standard deviation with regards to the number of researches conducted by the advance higher education faculty members are good evidence of limited research productivity of the university. This evidently showed the country's problems in terms of maintaining the balance between the mandates of instructions and research in the advance higher education (David et al, 2020). In terms of performance rating, the majority of the advance higher education faculty members are 'very satisfactory' that can further display their degree of teaching proficiency.

The next research question of the study was to identify the academic performance of the advance higher education students in terms of their basic, major, and elective subjects. 
Patimo, D.M. \& Lucero, M.B.A., Predictors of Success in Advance Higher Education: A Case in Northwest Samar State University, Philippines

Table 3 displays the academic performance of the advance higher education students in terms of basic, major, and elective subject areas. As observed, passing grades were obtained by the advance higher education students on basic, major, and elective subject areas. This is also true in the study of Mendoza (2020) with the academic performance graduate students in a State College in Northern Leyte, Philippines. These data further show the good scholastic performance of the advance higher education students that prove their motivation to learn important knowledge, skills, and attitude in their field of specializations.

Table 3: Mean and Standard Deviations on the Academic Performance of the Advance Higher Education Students of Northwest Samar State University

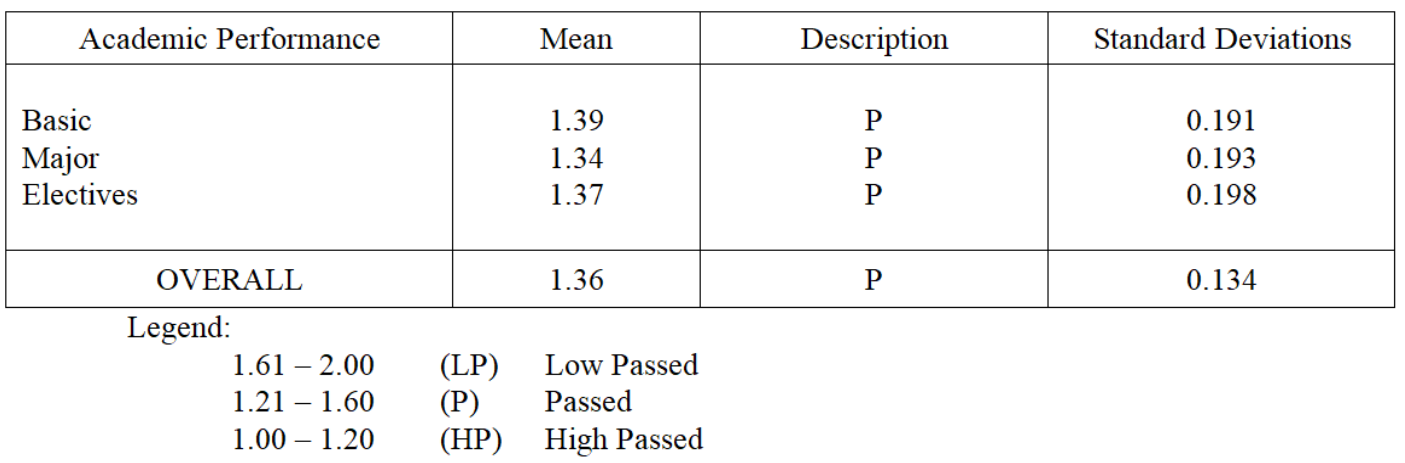

The last research question addressed in this study was to determine the profile variable of the advance higher education faculty members that best predict the academic performance of their students. Table 4 displays the stepwise multiple regression analysis of the profile of the advance higher education faculty members concerning the scholastic performance of their students. The result revealed the predictor for the scholastic performance of the advance higher education is the work experience of advance higher education faculty members.

These findings were supported in the study of Hamilton et al (2015). Their study postulated that teachers matter most to the student's academic performance. When it comes to student performance, the teacher factor is estimated to have twice or thrice the impact compared to any other school factors. Another study found that the teachers can contribute as much as the students' capacities and abilities to student learning (Gairola, 2019; Morteza \& Khademi, 2015). Also, Wenglingsky (2001) suggested that teachers' sources of pedagogical beliefs and teachers' teaching experiences are the main predictors of learners' outcomes. 
Patimo, D.M. \& Lucero, M.B.A., Predictors of Success in Advance Higher Education: A Case in Northwest Samar State University, Philippines

Table 4: Stepwise Multiple Regression Analysis of the Profile of the Advance Higher Education Faculty Members with Respect to Academic Performance of their Students

\begin{tabular}{|l|c|c|c|}
\hline \multirow{2}{*}{ Profile Variables } & \multicolumn{3}{c|}{ Academic Performance } \\
\cline { 2 - 4 } & Beta & $\mathrm{t}$ & Sig. \\
\hline Constant & 1.609 & 9.857 & 0.000 \\
\hline Age & 0.087 & 0.286 & 0.778 \\
\hline Sex & 0.298 & 1.492 & 0.153 \\
\hline Rank & 0.173 & 0.583 & 0.567 \\
\hline Work Experience & $0.584^{* *}$ & 3.135 & 0.005 \\
\hline Number of Trainings/ Seminars Attended & -0.250 & -1.369 & 0.188 \\
\hline Net Take Home Pay & 0.103 & 0.480 & 0.637 \\
\hline Number of Researches Conducted & -0.028 & -0.145 & 0.887 \\
\hline Performance Rating & 0.085 & 0.411 & 0.686 \\
\hline \multicolumn{2}{|c|}{0.341} \\
\hline R-Square & \multicolumn{3}{|c}{0.306} \\
\hline Adjusted R-Square & $9.825^{* *}$ & 0.005 \\
\hline F-Ratio & \multicolumn{3}{|c}{} \\
\hline p-value &
\end{tabular}

In relation to this, Demirham and Yucel (2016) concluded in their study that the teacher commitment can be predicted by their marital status and working time. This is also supported with a linear regression study of Bittman and Russell (2016) when they found out that the instructional pedagogies of experienced teachers increase student performance.

\section{Conclusion}

The success in advance higher education can be primarily predicted with the work experience of the faculty members. Good or bad academic performance of the advance higher education students primarily dependent to the work experience of their faculty members. Faculty members with high work experience usually denote good academic performance of their students. On the other hand, low work experience among faculty members denotes low academic performance of their students. More experienced faculty members in the university have more relevant trainings or seminars attended, more researches conducted, good performance rating, and higher net take home pay. With this, their students are more motivated to learn and to equip with the necessary knowledge and skills to be successful in their advance higher education studies. Work experience of the advance higher education faculty members may be considered as important criteria for the recruitment and selection of faculty members in masteral and doctorate programs of the university. Results of this study are primarily limited in the case of the Northwest Samar State University that offers graduate programs in the Philippine settings. 
Patimo, D.M. \& Lucero, M.B.A., Predictors of Success in Advance Higher Education: A Case in Northwest Samar State University, Philippines

\section{References}

Alyahyan, E. \& Düştegör, D. (2020). Predicting academic success in higher education: literature review and best practices. Int J Educ Technol High Educ 17(3). https://doi.org/10.1186/s41239-020-0177-7

Bhatti, M.T. \& Qazi, W. (2011). Parental Support, Self-Concept, Motivational Orientations, and Teacher-Student Relationship, and Academic Competence: An Exploratory Analysis, 2011, 6(4), 203-214.

Bilbao, P., Corpuz, B., \& Llagas, A. (2012). The Teaching Profession Second Edition. Lorimar Publishing Inc.

Bittman, B., \& Russell, W. (2016). Civic education in United States: A multiple regression of civic education scores from the national assessment of educational progress. Research in Social Sciences and Technology, 1(2). https://doi.org/10.46303/ressat.01.02.1

Bulut, I., \& Yilmaz, F. (2014). The Relationship between Mathematics Teachers' Democratic Behavior and Students' Mathematics Success, International Online Journal of Educational Sciences, 6(3), 626-637.

Ching Jr, J. P., \& Patimo, D. M. (2021). Effectiveness of the MIS Units in SUCs Samar-Leyte Islands through Management Functions: Administrators and MIS Personnel Perspective. Asian Journal of Research in Computer Science, 13-21.

Clarke, B., Clarke, D., Sullivan, P. \& O'Shea, H. (2010). Exploring the Relationship between Task, Teacher Actions, and Student Learning, PNA, 4(4), 133-142.

Danielson, C. (2006). Teacher leadership that strengthens professional practice. ASCD.

David, A. P., Reyes, Z. Q., Miranda, P. A., Nalipay, M. J. N., Ancho, I. V., \& Roxas, M. M. (2020). Graduate Teacher Education in the Philippines: Observations and Prospects. The Normal Lights, 14(2).

Denessen, E., Vos, N., Hasselman, F., \& Louws, M. (2015). The Relationship Between Primary School Teacher and Student Attitudes towards Science and Technology, Education Research International, 2015.

Demirhan, G., \& Yucel, C. (2016). A prediction for teacher commitment; Effects of managerial style, burnout and demographics. Research in Social Sciences and Technology, 1(1), 2443. https://doi.org/10.46303/ressat.01.01.2 
Patimo, D.M. \& Lucero, M.B.A., Predictors of Success in Advance Higher Education: A Case in Northwest Samar State University, Philippines

Dinh, H. (2019). Towards a Knowledge-rich Curriculum. Journal of Curriculum Studies Research, 1(1), 54-70. https://doi.org/10.46303/jcsr.01.01.5

Gairola, R. (2019). Attitudes of secondary teacher trainees towards entrepreneurial education. Research in Educational Policy and Management, 1(1), 44-54. https://doi.org/10.46303/repam.01.01.4

Gwen, Bug (June 12, 2011). How Undergraduate and Graduate School are Different. Retrieved November 20, 2015 from https://membracid.wordpress.com/2011/06/12/howundergraduate-and-graduate-school-are-different.

Hamilton, L. S., Engberg, J., Steele, J. L., \& Mihaly, K. (2015). Teachers Matter: Understanding Teachers' Impact on Student Achievement. Retrieved November 18, 2015 from http://www.rand.org/education/projects/measuring-teachereffectiveness/teachersmatter. html.

Hashmi, M. A., Zeeshan, A., Raza, S. A., Memood T. \& Shaikh, F. M. (2011). Investigating Teachers' Academic Excellence as a Predictor of Acceptable Teaching through Students' Evaluation of Teachers. Asian Social Science, 7(10).

Lee, A., \& Lee, A. (2020). Experience with Diversity is Not Enough: A Pedagogical Framework for Teacher Candidates that Centers Critical Race Consciousness. Journal of Curriculum Studies Research, 2(2), 40-59. https://doi.org/10.46303/jcsr.2020.9

McCorkle, W. (2020). Problematizing Immigration Restrictions during COVID-19 in the Social Studies Classroom. Research in Social Sciences and Technology, 5(3), 1-24. https://doi.org/10.46303/ressat.05.03.1

Mendoza, A. D. (2020). Precursors of Academic Performance of Graduate Students in a State College in Northern Leyte, Philippines. Solid State Technology, 10263-10276.

Monga, S., \& Ye, Y. (2020). A Study of Teachers' Perceptions Towards Interpersonal Relationship and Working Environment with Their Demographic Profile at Roong Aroon School, Thailand. Scholar: Human Sciences, 12(1), 377-377.

Morteza, M. \& Khademi, M. (2015). The Relationships among Sources of Teacher Pedagogical Beliefs, Teaching Experiences, and Student Outcomes, International Journal of Applied Linguistics and English Literature, 4(2), 177-184.

Ngoma, M., Ntale, P. D., \& Abaho, E. (2017). Social-economic factors, student factors, student academic goals and performance of students in institutions of higher learning in Uganda. Africa Education Review, 14(2), 106-121. http://dx.doi.org/10.1080/18146627.2017.1286941 
Patimo, D.M. \& Lucero, M.B.A., Predictors of Success in Advance Higher Education: A Case in Northwest Samar State University, Philippines

Pangandaman, H. K., Ali, N. D., Lambayong, J. C., \& Ergas, M. G. (2019). Philippine Higher Education Vis-À-Vis Education 4.0: A Scoping Review. International Journal of Advanced Research and Publications, 3(3), 65-69.

Patimo, D. M., \& Maribojoc, R. P. (2021). University Electronic Records Management System for Northwest Samar State University, Calbayog City. Logic: Jurnal Rancang Bangun dan Teknologi, 21(1), 1-7.

Patimo, D. (2020). Faculty Performance Evaluation System of State Universities and Colleges in the Philippine Eastern Visayas Region. JISAE: Journal of Indonesian Student Assessment and Evaluation, 6(2), 159-167. https://doi.org/10.21009/JISAE.062.06

Pokhrel, S., \& Chhetri, R. (2021). A Literature Review on Impact of COVID-19 Pandemic on Teaching and Learning. Higher Education for the Future, 8(1), 133-141. https://doi.org/10.1177/2347631120983481

Torabi, A. \& Zahiri, M. (2012). Study on Influencing Factors Relationship between Teacher and Student in view of Students of Ahvaz University of Medical Sciences, Jundishapur Scientific Medical Journal, 11(5), 549-557.

Waychunas, W. (2020). Where Teachers Thrive: A book review. Research in Educational Policy and Management, 2(2), 129-132. https://doi.org/10.46303/repam.2020.7

Wenglinsky, Harold (September 2001). Teacher Classroom Practices and Student Performance: How Schools Can Make a Difference. Retrieved November 18, 2015 from https://www.ets.org/Media/Research/pdf/RR-01-19-Wenglinsky.pdf.

Wenner, J. A., \& Campbell, T. (2017). The Theoretical and Empirical Basis of Teacher Leadership: A Review of the Literature. Review of Educational Research, 87(1), 134171. https://doi.org/10.3102/0034654316653478

Wren, J. \& Wren, B. (2009). Enhancing learning by integrating theory and practice. International Journal of Teaching and Learning in Higher Education, 21(21), 258-265. 